\title{
ON THE MOSS FLORA OF TARDOKI-YANI MOUNTAIN (NORTH SIKHOTE-ALIN, RUSSIAN FAR EAST)
}

\author{
К ФЛОРЕ МХОВ ГОРЫ ТАРДОКИ-ЯНИ (СЕВЕРНЫЙ СИХОТЕ-АЛИНЬ, \\ РОССИЙСКИЙ ДАЛЬНИЙ ВОСТОК)
}

\author{
VLADIMIR E. FEDOSOV ${ }^{1}$, ALEXANDER V. ERMOLENKO ${ }^{2}$, DARIA E. KOLTYSHEVA ${ }^{1} \&$ \\ VADIM A. BAKALIN ${ }^{2}$ \\ ВЛАДИМИР Э. ФЕДОСОВ ${ }^{1}$, АЛЕКСАНДР В. ЕРМОЛЕНКО ${ }^{2}$, ДАРЬЯ Е. КОЛТЫШЕВА ${ }^{1}$, \\ ВАДИМ А. БАКАЛИН ${ }^{2}$
}

Abstract

\begin{abstract}
Annotated list of 145 mosses collected on the Tardoki-Yani Mt is presented. Annotations provide data on altitudinal distribution of each species, ecology and accompanying species. The specificity of the forest belt in the area comprises the addition of hemiboreal East Asian species to the generally boreal species composition. Brachythecium garovaglioides is newly found in Russia. Other interesting species include Oedipodium griffithianum, Pohlia vexans, Sphagnum alaskense and two tentatively undescribed species of the genera Dicranum and Seligeria; the latter are supplied with additional comments. Twenty nine species are newly reported for the Sikhote-Alin; some of these species have mainly arctic-alpine distribution and are found on the Tardoki-Yani Mt quite far from the area of their continuous distribution.
\end{abstract}

Резюме

Во флоре мхов горы Тардоки-Яни, высшей точки Сихоте-Алиня, выявлено 145 видов. Приводится аннотированный список, включающий данные о высотном интервале, где вид отмечался, его экологии и сопутствующих видах. В лесном поясе преобладают бореальные мхи, к которым добавляется ряд восточно-азиатских видов. В альпийском и субальпийском поясах встречается множество арктоальпийских и горных видов, а также некоторые виды, распространение которых недостаточно изучено. Подтверждено произрастание в России Brachythecium garovaglioides, среди других интересных находок-Oedipodium griffithianum, Pohlia vexans, Sphagnum alaskense, а также не описанные виды из родов Dicranum и Seligeria, которые снабжены дополнительными комментариями. 29 видов ранее не приводились для Сихоте-Алиня; в основном это арктоальпийские виды, обнаруженные здесь в существенном удалении от районов их широкого распространения.

KEYWORDS: mosses, rare species, Khabarovsk Territory, Sikhote-Alin Range, Russian Far East

\section{INTRODUCTION}

Moss flora of the Sikhote-Alin mountain Range catches attention of bryologists during at least the past century, but it still remains fragmentarily studied. Bardunov \& Cherdantseva (1982) listed 420 moss species for the southern part of Primorsky Territory. During the last decade a number of field trips aiming bryophyte flora exploration were organized to the southern and middle parts of the Sikhote-Alin Range. These trips resulted in many curious and interesting records (Ignatov et al., 2006, 2007,2013 , etc.), while less remarkable ones mostly remained unpublished. In general, only two well studied local moss floras of the Southern Sikhote-Alin are pub- lished, i.e., moss flora of Ussurijsky Nature Reserve (233 species, Bardunov \& Cherdantseva, 1978) and of Lazovsky Nature Reserve (215 species, Bardunov et al., 1990). In the middle part of the Sikhote-Alin Range, list of 191 species was published for the Sikhote-Alinsky State Reserve (Cherdantseva, 2002), whilst being supplemented by the data on flora of Terneisky District of Primorsky Territory (Bardunov \& Cherdantseva, 1982), this number reaches 206 species. The only sufficient published data on the moss flora of the Northern Sikhote-Alin is a preliminary list of mosses of Botchinsky Nature Reserve (Ignatova et al., 2013), where 239 species were revealed. However, Botchinsky Reserve is situated in foothill area

1 - Moscow State University, Faculty of Biology, Geobotany Dept., Leninskie Gory Str., 1-12, Moscow 119234 Russia - Poccия 119234, Москва, Ленинские горы 1-12, Московский Государственный университет, Биологический факультет, кафедра геоботаники; e-mail: fedosov v@mail.ru, danauserippus@mail.ru

2 - Botanical Garden-Institute FEB RAS, Makovskogo Street, 142, Vladivostok, 690024, Russia - Ботанический сад-институт ДВО РАН, ул. Маковского, 142, Владивосток, 690024; e-mail: vabakalin@gmail.com 


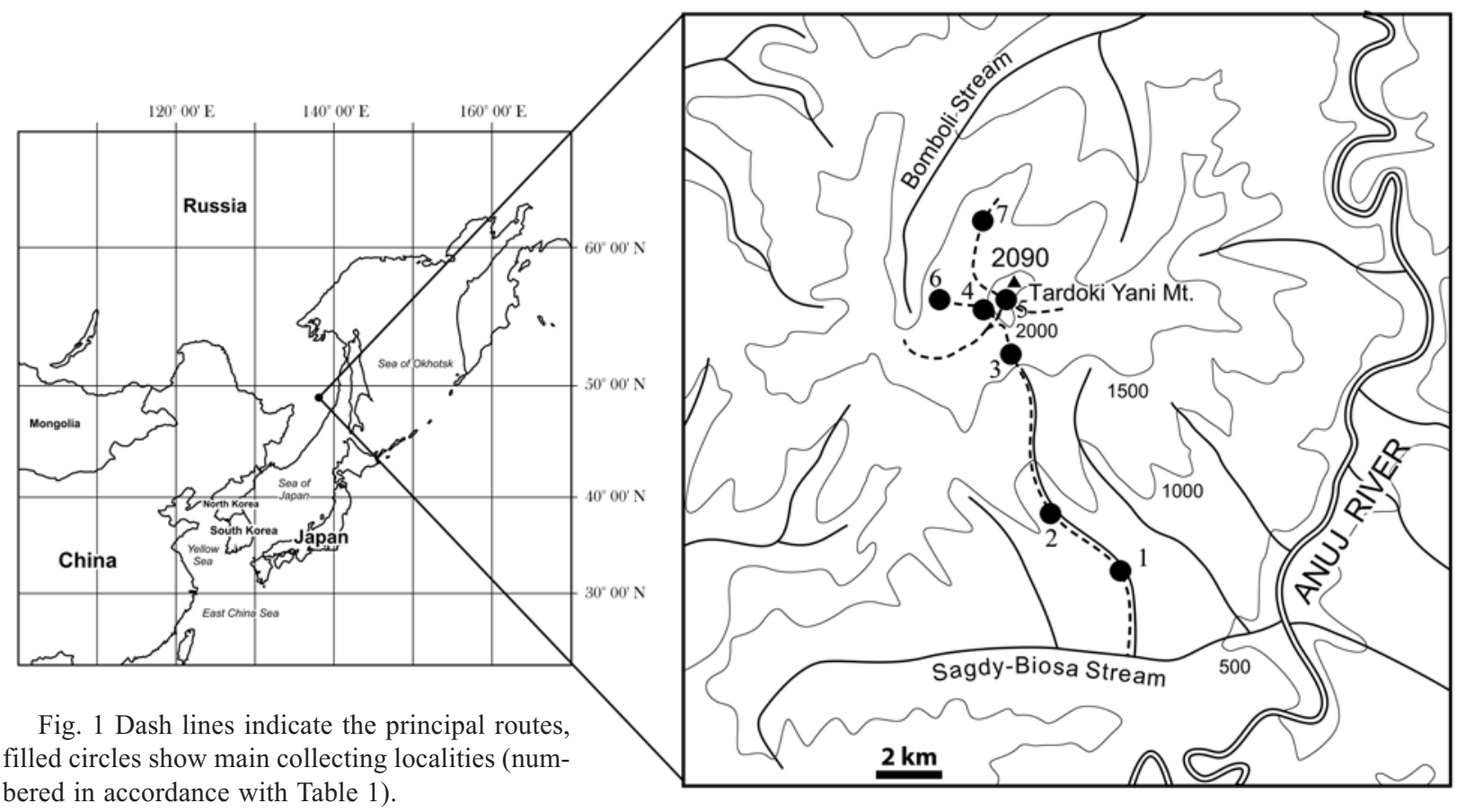

bered in accordance with Table 1).

with altitudinal range $230-630 \mathrm{~m}$, thus its territory does not reflect all diversity of landscapes and habitats of the Northern Sikhote-Alin, where the highest point of the range (the Tardoki-Yani Mt., $2090 \mathrm{~m}$ a.s.1.) is situated.

In August of 2013 Bakalin and Ermolenko visited the Tardoki-Yani Mt., aiming exploration of the bryophyte flora. Liverwort flora of the area was recently published by Bakalin (2015), who revealed there a large southern refugium of Arctic-alpine hepatics. Such result could be expected as the summit area of the TardokiYani Mt. (2090 m alt.) is covered by true alpine tundra, alternated with rock fields, cliffs, alpine meadows and bogs. True snowbeds are absent in the study area, although in some places near mountain summit snow-melting season ends at the middle of August.

The results of identification of mosses collected on the Tardoki-Yani Mt. in 2013 are presented here.

\section{MATERIAL AND METHODS}

The study area is described in details in Bakalin (2015). The set of ca. 350 moss specimens was collected in the Tardoki-Yani Range in 20-28 August 2013 by Ermolenko and Bakalin and was later identified by Fedosov; some specimens of Sphagnum were checked by A.I. Maksimov. Sphagnum beringiense A.J. Shaw, R.E. Andrus \& B. Shaw revealed in this collection was published by Maksimov et al. (2016). A primary list was compiled by $\mathrm{D}$. Koltysheva. The list of collection localities is provided in Table 1; it corresponds to the map in Fig. 1.

\section{RESULTS}

Below we provide the list of taxa; nomenclature follows Ignatov, Afonina, Ignatova et al. (2006), with a few recent updates. Each species name is followed by locality numbers (in accordance with the table 1), altitude, brief description of ecology and list of accompanying taxa (if any). Aforementioned information is sometimes supplemented by some notes or literature references. Specimens are kept in MW, with duplicates in VBGI.

Abietinella abietina - 3, 5 - 1930-2090 m - On soil in dry to mesic places in alpine belt. In pure mats or with Aulacomnium turgidum, Rhytidium rugosum, Sanionia uncinata.

Amphidium lapponicum - 4, 7 - 1880-2010 m - On cliffs in subalpine and alpine belts. In pure mats or with Brachythecium cirrosum, Bucklandiella microcarpa, Distichium capillaceum, Myurella julacea, Plagiothecium cavifolium.

*Andreaea alpestris $-\mathbf{4}-2000 \mathrm{~m}$ - On dry open cliff. In pure mat (only one collection).

A. rupestris $-\mathbf{2}, \mathbf{3}, \mathbf{5}, \mathbf{7}-871-2090 \mathrm{~m}-$ On dry to mesic cliffs and boulders in open places. In pure mats or with Arctoa fulvella, Iwatsukiella leucotricha, Hypnum cupressiforme.

Anoectangium stracheyanum - 1 - $617 \mathrm{~m}$ - On soil in coniferous forest. In pure mat (only one collection).

*Arctoa fulvella - 3-5, 7 - 1880-2090 m - In cliff crevices, on boulders and soil rich in humus in subalpine and alpine belts. In pure mats or with Andreaea rupestris, Isopterygiopsis muelleriana, Pohlia cruda.

Aulacomnium palustre - 6 - $1687 \mathrm{~m}$ - On soil in tundra. In pure mats or with Dicranum bonjeanii.

A. turgidum - 3-5 - 1925-2090 m-On soil and cliffs in open to partly shaded places in alpine belt. In pure mats or with Rhytidium rugosum, Sanionia uncinata, Abietinella abietina, Dicranum majus, Loeskypnum badium, Polytrichum hyperboreum, Ptilium crista-castrensis, Sphagnum warnstorfii, Warnstorfia exannulata.

Bartramia ithyphylla - 4, $7-1880-2050$ - On open to partly shaded cliffs and on soil in subalpine and alpine belts. In pure mats or with Oligotrichum parallelum, Pohlia drummondii.

B. pomiformis - 1,3-615, $1930 \mathrm{~m}$ - On partly shaded cliffs in alpine belt and on soil in coniferous forests. In pure mats or 
Table 1. Collecting localities in Tardoki-Yani Range

Locality Coordinates Geographic description, belt and characteristic vegetation type Date number

540-760 m alt. Coniferous forest with shrub-moss cover, mixed forest in the flood plain Coniferous forest with shrub-moss cover

Tardoki-Yani Mt. Range, ca. 2-2.5 km westward of Tardoki-Yani Mt. top; 1825-1925 m alt. gravely barrens and rock fields

with Anoectangium stracheyanum, Pohlia cruda.

Bartramiopsis lescurii - 1, 3 - 765, $1930 \mathrm{~m}$ - On shaded soil on steep slope in coniferous forest and on partly shaded cliffs in alpine belt. With Ditrichum heteromallum and Plagiopus oederianus.

Blindia acuta - 4 - $1940 \mathrm{~m}$ - On rock in cavity at cliff base, with Cyrtomnium hymenophylloides (only one collection).

Brachytheciastrum trachypodium - 4 - $2050 \mathrm{~m}$ - In shaded cliff crevice in alpine belt. With Isopterygiopsis muelleriana and Plagiothecium laetum (only one collection).

*Brachythecium cirrosum -4 - $2010 \mathrm{~m}$ - In rock crevice filled with humus. With Amphidium lapponicum, Bucklandiella microcarpa, Distichium capillaceum, Myurella julacea (only one collection).

*B. garovaglioides $-4-1940 \mathrm{~m}$ - On soil on moist open slope in the alpine belt. With Philonotis fontana, Loeskypnum badium, Campylium stellatum, Hylocomiastrum pyrenaicum (only one collection).

Bryum pseudotriquetrum - 5 - $2090 \mathrm{~m}$ - On soil in alpine tundra. In admixture to Loeskypnum badium (only one collection).

Bucklandiella microcarpa - 3-5 - 1925-2090 m - On cliffs and boulders in alpine belt. In pure mats or with Amphidium lapponicum, Brachythecium cirrosum, Distichium capillaceum, Hymenoloma crispulum, Myurella julacea.

Buxbaumia minakatae - 1 - $543 \mathrm{~m}$ - On decaying wood in rather open place in coniferous forest. With Dicranum montanum (only one collection).

Campylium stellatum - 5 - $2090 \mathrm{~m}$ - On soil in alpine tundra. In pure mat (only one collection).

Ceratodon purpureus - 3, 5 - 1920-2090 m - On soil and plant debris covering rocks in alpine belt. With Hymenoloma crispulum, Rhytidium rugosum.

Climacium japonicum - 1 - $617 \mathrm{~m}$ - On partly shaded soil in coniferous forest. In pure mat (only one collection).
*Cnestrum alpestre - 4 - $1940 \mathrm{~m}$ - In shaded cavity at cliff base. In pure mat (only one collection).

Codriophorus brevisetus $-\mathbf{1}-765 \mathrm{~m}$ - On shaded wet boulder near brook in coniferous forest belt. With Sciuro-hypnum plumosum (only one collection).

*Conostomum tetragonum - 3, 5 - 1925-2090 m - On soil and cliffs in alpine belt. In pure mats.

Cynodontium strumiferum - 4 - $1940 \mathrm{~m}$ - On boulder in subalpine tundra. In pure mat.

Cyrtomnium hymenophylloides - 4 - 1940 m - In cavity at cliff base. In pure mat (only one collection).

Dicranella curvipes - 1 - $965 \mathrm{~m}$ - On shaded eroded soil on steep slope. With Pogonatum urnigerum, Schistostega pennata.

D. subulata - 4-1940 m - On moist soil in alpine belt. With Pogonatum dentatum (only one collection).

Dicranodontium denudatum - 1-3 - 540-875, 1927 m - On partly shaded soil, boulders and decaying wood in coniferous forest and on gravelly barrens, on open soil in alpine tundra. In pure mats or with Heterophyllium affine, Tetraphis geniculata.

*Dicranum angustum - 5 - $2090 \mathrm{~m}$ - On wet soil in alpine belt. With Loeskypnum badium (only one collection).

D. bonjeanii-6-1687 m-On soil in wet tundra. In pure mats or with Aulacomnium palustre.

D. elongatum - 3, 5 - 1925-2090 m - In wet alpine tundra. In pure mats or with Isopterygiopsis muelleriana.

D. flagellare - 1-543 m- On a tree trunk in rather open place in coniferous forest. With Glyphomitrium humillimum (only one collection).

D. fragilifolium - 3-1927 m - On boulder in rock field in alpine belt. In pure mat (only one collection).

D. fuscescens $-7-1884 \mathrm{~m}-$ On soil in shaded cavity at cliff base in subalpine belt. With Pleurozium schreberi and Sanionia uncinata (only one collection). 
D. majus - 3-5 - 1925-2090 m - On soil and cliffs in alpine belt. In pure mats or with Aulacomnium turgidum, Loeskypnum badium, Plagiomnium confertidens, Polytrichastrum alpinum. Ptilium crista-castrensis, Sanionia uncinata, Sphagnum warnstorfii.

D. montanum - 1 - 540-770 $\mathrm{m}$ - On partly shaded decaying wood in coniferous forest belt. In pure mats or with other epyxilic mosses and liverworts.

D. schljakovii - 3 - $1930 \mathrm{~m}-$ On soil in tundra belt. With Racomitrium lanuginosum and Abietinella abietina (only one collection).

D. scoparium - 1, 2, 7 - 540-1885 m - On boulders, soil, decaying wood and tree trunks in coniferous forest and subalpine belt. In pure mats or with Leucodon pendulus, Pleurozium schreberi, Rhytidiadelphus triquetrus.

D. septentrionale -4 - 1940-2010 m - On open mesic slopes and cliffs in alpine belt. In pure mats.

$* D$. sp. $-4-2010 \mathrm{~m}-$ In shaded cliff crevice in alpine belt (only one collection).

Distichium capillaceum - 4, 5 - 19402090 m - In rock crevices filled by humus and niches of cliff walls in alpine belt. In pure mats or with Amphidium lapponicum, Brachythecium cirrosum, Bucklandiella microcarpa, Myurella julacea.

Ditrichum heteromallum - 3, 4-1925-2010 m - On cliffs in alpine belt. In pure mats or with Bartramiopsis lescurii, Isopterygiopsis muelleriana, Oedipodium griffithianum.

Encalypta ciliata - 4, 7 - 1880-1940 m - In shaded cavity at cliff base in alpine belt and on soil in subalpine community. With Flexitrichum flexicaule, Hypnum cupressiforme, Oxystegus tenuirostris, Saelania glaucescens.

Eurhynchiastrum pulchellum - 1 - 543 m - On soil and decaying wood in partly shaded places in coniferous forests. In pure mats or with Hylocomium splendens.

Flexitrichum flexicaule -4 - $1940 \mathrm{~m}$ - In shaded cavity at cliff base in alpine belt. With Encalypta ciliata (only one collection).

Glyphomitrium humillimum - 1 - 540-770 m - On tree trunks and decaying wood in partly shaded places in coniferous forest. In pure mats or with Dicranum flagellare and Pylaisia polyantha.

Grimmia donniana -3, 4-1925-2010 m - On cliffs and boulders in alpine belt. In pure mats or with Kiaeria falcata.

G. jacutica - 3 - $1927 \mathrm{~m}$ - On boulder in gravelly barren. In pure mat (only one collection).

G. longirostris - 4-2048 m - On open dry cliff in alpine belt. In pure mat (only one collection).

G. reflexidens - 3, 7-1880-1930 m- On cliffs and boulders in subalpine and alpine belts. In pure mats.

${ }^{*}$ G. torquata $-4-1940-2010 \mathrm{~m}-$ On cliffs in alpine belt. In pure mats.

Heterophyllium affine - $\mathbf{1}-543 \mathrm{~m}$ - On partly shaded decaying wood in coniferous forest. With Dicranodontium denudatum, Tetraphis geniculata (only one collection).

Homalia trichomanoides - 1, 3-765, $1927 \mathrm{~m}$ - On tree trunks in coniferous forest and on cliffs in alpine belt, in partly shaded places. With Hypnum cupressiforme, Neckera pennata, Rhizomnium nudum, Rhytidiadelphus japonicus, Saelania glaucescens.

Hygrohypnella ochracea - 1 - $617 \mathrm{~m}$ - On a partly shaded submerged boulder in the stream. In pure mat (only one collection).

H. polare $-\mathbf{6}-1687 \mathrm{~m}-$ On rocky soil near stream in alpine belt. With Warnstorfia sarmentosa (only one collection).
Hylocomiastrum pyrenaicum -5, 7 - 1880-2090 m-On cliffs, boulders and soil in subalpine and alpine belts. In pure mats or with Plagiothecium denticulatum, Sanionia uncinata, Schistidium lancifolium.

Hylocomium splendens - 1, 5, 7 - 540-2090 m - On decaying wood, soil and cliff crevices in coniferous forest to alpine belt. In pure mats or with Eurhynchiastrum pulchellum, Stereodon plicatulus, Thuidium assimile.

*Hymenoloma crispulum - 4, 5, 7 - 1880-2090 m - On cliffs and soil in open places in subapine and alpine belts. In pure mats or with Bucklandiella microcarpa, Ceratodon purpureus.

Hypnum cupressiforme - 2, 3, 7 - 870-1930 m - On partly shaded boulders and soil, from coniferous forest to alpine belt. With Saelania glaucescens, Andreaea rupestris, Encalypta ciliata, Homalia trichomanoides, Isopterygiopsis muelleriana, Oxystegus tenuirostris, Rhabdoweisia crispata.

Isopterygiopsis muelleriana - 1-4-615-2010 m - Mostly on mesic cliffs and boulders, as well as on soil in coniferous forest and alpine belts. In pure mats or with Oedipodium griffithianum, Rhabdoweisia crispata, Arctoa fulvella, Dicranum elongatum, Ditrichum heteromallum, Hypnum cupressiforme, Pohlia cruda, Polytrichum juniperinum, Saelania glaucescens.

I. pulchella - 1, 4, 5, 7 - 765-2090 m - On soil and decaying wood in mesic conditions in coniferous forest to alpine belt. In pure mats or with Saelania glaucescens.

Iwatsukiella leucotricha - 1, 3, 7 - 540-1930 m - On tree trunks and branches in coniferous forest and on cliffs in subalpine and alpine belts. In pure mats or with Andreaea rupestris.

*Kiaeria blyttii - 5 - $2090 \mathrm{~m}$ - On open dry cliff. In pure mat (only one collection).

*K. falcata - 4 - $2010 \mathrm{~m}$ - In a cliff crevice in shaded place. With Grimmia donniana (only one collection).

*K. starkei-3, 4-1925-2010 m - On boulders in alpine belt. In pure mats.

Lescuraea saxicola - 7 - $1884 \mathrm{~m}$ - In shaded cliff niche on a steep slope in subalpine belt. In pure mat (only one collection).

Leucodon pendulus - 1 - 540-765 m - On tree trunks and branches in coniferous forest belt.

*Loeskypnum badium - 4, 5 - 2010-2090 m - On soil in wet tundra and turf-covered rocks. In pure mats or with Aulacomnium turgidum, Dicranum majus, Sphagnum beringiense, S. warnstorfii, Bryum pseudotriquetrum, Dicranum angustum.

Mnium lycopodioides - 1 - $543 \mathrm{~m}$ - On litter in partial shade. With Rhytidiadelphus japonicas (only one collection).

M. marginatum - $1-765 \mathrm{~m}$ - On partly shaded tree trunk. With Thuidium assimile (only one collection).

M. spinosum - 3, 4-1925-1940 m - On shaded cliff walls and humus in crevices in mesic conditions in alpine belt. In pure mats.

*Myurella julacea - 4-2010 m - In rock crevices filled with humus in alpine belt. With Amphidium lapponicum, Brachythecium cirrosum, Bucklandiella microcarpa, Distichium capillaceum (only one collection).

Neckera pennata - 1 - 610-765 m - On partially shaded tree trunks, rarely on decaying wood. In pure mats or with Homalia trichomanoides, Leucodon pendulus, Rhytidiadelphus japonicus. 
Niphotrichum canescens $\mathbf{- 5}-2090 \mathrm{~m}$ - In pure mat in gravelly barren (only one collection).

$N$. panschii $-\mathbf{3}-1825 \mathrm{~m}-$ On boulder in alpine tundra. In pure mat (only one collection).

Ochyraea duriuscula -1 - $765 \mathrm{~m}$ - On partly shaded wet boulder near stream in coniferous forest belt. With Pseudohygrohypnum subeugyrium (only one collection).

Oedipodium griffithianum - 3-5 - 1925-2090 m - On soil in shaded cliff niches and among boulders in mesic conditions. In pure mats or with Isopterygiopsis muelleriana, Ditrichum heteromallum, Polytrichum juniperinum.

*Oligotrichum falcatum - 5 - 2090 m - On soil in tundra. In pure mats (only one collection).

O. parallelum - 3, 4, 7 - 1880-2050 m - On soil in open places in subalpine and alpine belts. In pure mats or with Bartramia ithyphylla, Pohlia drummondii, Polytrichastrum alpinum.

Oncophorus wahlenbergii - 1, 3 - 540-765, 1927 m - On decaying wood in coniferous forest and on soil in alpine tundra. In pure mats or with Plagiothecium denticulatum.

Oxystegus tenuirostris - 7 - $1884 \mathrm{~m}$ - On soil in subalpine community. With Encalypta ciliata, Hypnum cupressiforme, Saelania glaucescens (only one collection).

Philonotis fontana - 5-2090 m - On open wet cliffs. With Warnstorfia sarmentosa (only one collection).

Plagiomnium confertidens - 1, 4-617, $2048 \mathrm{~m}$ - On decaying wood in coniferous forest and on soil in alpine tundra. In pure mats or with Dicranum majus, Ptilium crista-castrensis, Sanionia uncinata.

P. cuspidatum - 1 - 543 m- On decaying wood in partial shade. In pure mats (only one collection).

Plagiopus oederianus - 1 - $765 \mathrm{~m}$ - On shaded steep slope in coniferous forest. In pure mats or with Bartramiopsis lescurii.

Plagiothecium cavifolium - 4 - 1940-2000 m - On soil on slopes, cliff ledges and at cliff bases in alpine belt. In pure mats or with Amphidium lapponicum.

P. denticulatum - 1, 3, 7-765-1930 m - On decaying wood in coniferous forest, on boulders and cliffs in shaded places in subalpine and alpine belts. In pure mats or with Hylocomiastrum pyrenaicum, Oncophorus wahlenbergii.

P. euryphyllum -1 -543 m - In pure mats on coniferous forest floor (only one collection).

Pleuroziopsis ruthenica $\mathbf{- 2}-871 \mathrm{~m}$ - On partly shaded place on steep slope in coniferous forest belt. In pure mat (only one collection)

Pleurozium schreberi - 7 - $1884 \mathrm{~m}$ - On soil, and turf-covered cliffs in subalpine belt. With Dicranum fuscescens, Dicranum scoparium, Sanionia uncinata.

Pogonatum dentatum - 4-1940 m - On bare soil in tundra. With Dicranella subulata (only one collection).

P. japonicum - 1-765 m - On soil on steep eroded slope in coniferous forest. In pure mat (only one collection).

P. urnigerum - 1, 5, 6-765-2090 m - On eroded soil in coniferous forest, subalpine and alpine belts. In pure mats or with Dicranella curvipes, Sanionia uncinata, Schistostega pennata.

Pohlia andrewsii - 4-1940 m - On soil in tundra. With Pohlia drummondii and Pohlia nutans (only one collection).

P. cruda-1, 7-610-1890 m-On soil and cliffs in coniferous forest and subalpine belts. With Anoectangium stracheyanum, Arctoa fulvella, Bartramia pomiformis, Isopterygiopsis muel- leriana, Polytrichastrum alpinum, Rhabdoweisia crispata. *P. drummondii - 4, 6 - 1685-2050 m - On bare soil in subalpine and alpine belts. With Bartramia ithyphylla, Oligotrichum parallelum, Pohlia andrewsii, Pohlia nutans, Sanionia uncinata.

*P. ludwigii-3 - $1927 \mathrm{~m}$ - On soil in cliff crevices on E-facing slope in alpine tundra. In pure mat (only one collection)

P. nutans - 4-6 - 1685-2090 m - On soil and in cliff crevices in alpine and subalpine belts. In pure mats or with Pohlia andrewsii, Pohlia drummondii.

*P. vexans $-7-1884 \mathrm{~m}-$ On bare soil in subalpine community. In pure mat (only one collection). The species occurs in cold continental areas of North America and European mountains. Distribution of the species in Asiatic part of Russia still little known, it also has been found in Altai Mts. (Ignatov, 1994) and Chukotka Peninsula (Afonina, 2004). Usually inhabits calcareous clay deposits.

P. wahlenbergii - 6-1687 m - In mesic tundra near stream. In pure mat (only one collection).

Polytrichastrum alpinum - 3, 4, 7 - 1880-2050 m - In cliff crevices and niches in alpine and subalpine belts. In pure mats or with Dicranum majus, Oligotrichum parallelum, Pohlia cruda.

Polytrichum commune - 1 - 617 m - On partly shaded rocks covered with in mixed forest in the flood plain. With Sphagnum squarrosum (only one collection).

*P. hyperboreum - 3, 6 - 1685-1930 m - In subalpine and alpine tundra. In pure mats or with Aulacomnium turgidum, Warnstorfia exannulata.

P. juniperinum - 3-1927 m - On a partly shaded turf-covered boulder in gravelly barren. With Isopterygiopsis muelleriana and Oedipodium griffithianum (only one collection).

*Pseudohygrohypnum subeugyrium - 1 - 765 m - On shaded boulder near stream in coniferous forest belt. With Ochyraea duriuscula (only one collection).

Pseudoleskeella papillosa - 3 - 1927 m - On boulder in gravelly barren. With Stereodon holmenii (only one collection).

P. tectorum - 4-1940 m - In shaded cliff niche in alpine belt. In pure mat (only one collection).

Pseudotaxiphyllum elegans - 4-2010 m - In shaded cliff crevice in alpine belt. In pure mat (only one collection).

Ptilium crista-castrensis - 1, 4, 5 - 765, 2045-2090 m - On soil in open to partly shaded places in coniferous forest and alpine belt. In pure mats or with Aulacomnium turgidum, Dicranum majus, Plagiomnium confertidens, Sanionia uncinata.

Pylaisia polyantha - 1 - $765 \mathrm{~m}$ - On partly shaded decaying wood. With Glyphomitrium humillimum (only one collection).

Pylaisiadelpha tristoviridis $\mathbf{- 4}-2010 \mathrm{~m}$ - On partly shaded boulder. In pure mat (only one collection).

Racomitrium lanuginosum - 3, 5 - 1925-2090 m - On soil in alpine belt. In pure mats or as an admixture to other alpine mosses.

Rhabdoweisia crispata - 1, 2 - 615-875 m - On partly shaded boulders in gravelly barrens in coniferous forest belt. In pure mats or with Isopterygiopsis muelleriana, Hypnum cupressiforme, Pohlia cruda.

Rhizomnium magnifolium - 6 - 1687 m - On partly shaded soil in subalpine belt. In pure mat (only one collection).

R. nudum - 1 - $765 \mathrm{~m}-$ On tree trunk in partial shade. With Homalia trichomanoides (only one collection). 
R. striatulum $-\mathbf{1}-765 \mathrm{~m}-$ On boulder near stream in coniferous forest. In pure mat (only one collection).

Rhytidiadelphus japonicus - 1 - 540-765 m - On tree trunks and forest floor in partly shaded places. With Homalia trichomanoides, Mnium lycopodioides, Neckera pennata.

R. triquetrus - 1, 2, 7 - 543-1884 m - On soil, decaying wood and tree trunks in partial shade in coniferous forest and subalpine belts. In pure mats or with Dicranum scoparium.

Rhytidium rugosum - 3, 5 - 1925-2090 m - On soil in alpine belt. With Aulacomnium turgidum, Abietinella abietina, Ceratodon purpureus, Sanionia uncinata.

Saelania glaucescens - 3-5, 7 - 1880-2090 m - On mineral ground and soil in partly shaded to open places in subalpine and alpine belts. In pure mats or with Hypnum cupressiforme, Encalypta ciliata, Homalia trichomanoides, Isopterygiopsis muelleriana, Isopterygiopsis pulchella, Oxystegus tenuirostris.

Sanionia uncinata - 1, 2, 5-7 - 765-2090 m - Mostly on soil, also on rocks, decaying wood and tree branches in all altitudinal belts. In pure mats or with Aulacomnium turgidum, Abietinella abietina, Dicranum fuscescens, Dicranum majus, Hylocomiastrum pyrenaicum, Plagiomnium confertidens, Pleurozium schreberi, Pohlia drummondii, Pogonatum urnigerum, Ptilium crista-castrensis, Rhytidium rugosum.

*Schistidium crenatum - 1 - 765 m - On partly shaded boulder near stream in coniferous forest. With Sciuro-hypnum plumosum (only one collection).

S. lancifolium - 7-1884 m- On rock in cliff niche in subalpine belt. With Hylocomiastrum pyrenaicum (only one collection).

*S. sordidum $-\mathbf{5}-1850 \mathrm{~m}-$ On open wet cliff. In pure mat (only one collection).

Schistostega pennata - 1 - $765 \mathrm{~m}$ - In fully shaded niche on steep slope in coniferous forest. With Dicranella curvipes, Pogonatum urnigerum (only one collection).

Sciuro-hypnum plumosum - 1, 6-610-2050 m - On rocks and soil along brooks in partly shaded places in coniferous forest, subalpine and alpine belts. In pure mats or with Schistidium crenatum, Codriophorus brevisetus.

S. reflexum - 7-1884 m-On soil in subalpine community. In pure mat (only one collection).

*Scorpidium revolvens - 5 - $2090 \mathrm{~m}$ - On wet rock surface. In pure mat (only one collection).

*Seligeria cf. diversifolia - 4-1940 m - On rock in moist cavity at cliff base in alpine belt (only one collection). The specimen has acute to rounded leaf apices and somewhat enlarged spores $15-18 \mathrm{~mm}$, while $S$. diversifolia s. str. mostly has acuminate leaf apices and spores $8-12(-14) \mathrm{Mm}$. Similar specimens were revealed in collections from some other area of Asian Russia. Preliminary molecular data (Fedosov \& Fedorova, 2015) have shown that these specimens represent a separate species. Its formal description is going to be published.

*Sphagnum alaskense - 3 - 1927 m - On moist turf-covered rock outcrop. In pure mat (only one collection). The species was recently described and shortly afterward revealed in Russia (Maksimov \& Ignatova, 2008). According to this data, it is scarcely distributed in Russian Far East, where it occurs in tundra and boggy forest, thus its presence in alpine communities of Tardoki-Yani Mt is quite expected.

*S. aongstroemii - 4-2010 m - On moist steep N-facing slope. In pure mat (only one collection).
S. beringiense - 4-2010 m - On moist rock base. With Loeskypnum badium (only one collection).

S. compactum - 3 - 1825-1930 m - On soil in tundra. In pure mats.

S. girgensohnii - 1, 3-5 - 765-2010 m - On soil in open to partly shaded places in coniferous forest and alpine belts. In pure mats.

S. squarrosum - 1-617 m - On wet turf-covered rocks in partial shade in mixed forest in creek valley. With Polytrichum commune (only one collection).

S. warnstorfii -4 $-2020 \mathrm{~m}-$ On moist rock base. With Aulacomnium turgidum, Dicranum majus, Loeskypnum badium (only one collection).

*Stereodon holmenii -3 - 1927 m - On partly shaded boulder in gravelly barren. With Pseudoleskeella papillosa (only one collection).

S. plicatulus - 3, 6, 7 - 1685-1930 m - On rocks and soil in subalpine and alpine belts. In pure mats or with Hylocomium splendens, Thuidium assimile.

Tetraphis geniculata - 1 - $543 \mathrm{~m}$ - On decaying wood in partial shade. With Dicranodontium denudatum, Heterophyllium affine (only one collection).

Tetraplodon mnioides $\mathbf{- 4}-2010 \mathrm{~m}$ - On rocks covered with humus. In pure mat (only one collection).

Thuidium assimile - 1, 7 - 543-1884 m - On decaying wood, tree trunks, soil and rocks in partial shade in coniferous forest and subalpine belts. In pure mats or with Hylocomium splendens, Mnium marginatum, Stereodon plicatulus.

Ulota reptans $-1-765 \mathrm{~m}$ - On partly shaded tree trunks. In pure mats.

Warnstorfia exannulata - 3 - $1927 \mathrm{~m}$ - On soil in mesic to submerged conditions in alpine tundra. In pure mats or with Aulacomnium turgidum, Polytrichum hyperboreum.

*W. sarmentosa - 3, 5, 6 - 1685-2090 m - On mesic to wet soil and rocks in alpine and subalpine belts. In pure mats or with Hygrohypnella polare, Philonotis fontana.

\section{DISCUSSION}

With 145 moss species the present list is far from representing real taxonomic diversity of mosses in the area. It is caused mostly by insufficiently explored forest belt, as the field trip was mostly focused on alpine communities, which are unique for the Sikhote-Alin. On the other hand, 60 species from the studied flora were not found in Botchinsky Reserve and thus are newly reported for the Northern Sikhote-Alin; 29 species have not been previously reported for the Sikhote-Alin in literature (Bardunov \& Cherdantseva, 1978; 1982; Bardunov et al., 1990; Cherdantseva, 2002; Ignatova et al., 2013 as well as numerous recently published papers, dealing with several genera, newly described or newly found species), though most of them were known to occur there. One species, Brachythecium garovaglioides Müll Hal., is newly found in Russia. List of species of the Tardoki-Yani Mt. comprises a number of arctic-alpine species, found here quite far from the area of their continuous distribution. Together with other rare and otherwise interesting mosses, the latter provide a background for brief phytogeographic discussion.

Even brief observation of present data suggests that boreal species are widespread and rather abundant in the 
forest belt. This 'boreal' flora is considerably enriched by such hemiboreal and nemoral East Asian species as Glyphomitrium humillimum, Ulota reptans, Tetraphis geniculata, Climacium japonicum, Buxbaumia minakatae, Leucodon pendulus, Pleuroziopsis ruthenica, Pogonatum japonicum, Plagiothecium euryphyllum, Pylaisiadelpha tristoviridis, Rhizomnium nudum, R. striatulum, and Rhytidiadelphus japonicus. At the same time, alpine belt of Tardoki-Yani Mt. houses several saxicolous arctic-alpine species and other species with generally more northern distribution that decrease their abundance southward. Among them Aulacomnium turgidum, Dicranum angustum, Scorpidium revolvens, Tetraplodon mnioides, Loeskypnum badium, Bartramia ithyphylla, Warnstorfia sarmentosa, Hygrohypnella polaris, Cnestrum alpesrte, Brachythecium cirrosum, Conostomum tetragonum, Flexitrichum flexicaule, Pogonatum dentatum, Racomitrium lanuginosum, Niphotrichum panschii, Sphagnum aongstroemii, Stereodon holmenii, Grimmia torquata should be listed. Alpine belt also houses numerous montane species which were not collected in the forest belt: Arctoa fulvella, Blindia acuta, Brachytheciastrum trachypodium, Dicranum schljakovii, D. septentrionale, Encalypta ciliata, Grimmia spp., Hylocomiastrum pyrenaicum, Hymenoloma crispulum, Kiaeria spp., Mnium spinosum, Oedipodium griffithianum, Oligotrichum falcatum, Pohlia andrewsii, P. drummondii, P. ludwigii, P. vexans, Polytrichastrum alpinum, Pseudoleskeella spp., Stereodon holmenii, etc. Several of them apparently occur at lower elevations as well, but were neglected due to less detailed study. At the same time, for instance, Oedipodi$u m$ is known to be restricted to the alpine belt. Several calciphilous mosses are likely associated with the alpine belt due to the rarity of calcareous rock outcrops in the area; some of them could be accidentally not collected at lower elevations due to the rarity of their habitats. Most acidophilous mosses are definitely associated with alpine and subalpine belts since granite outcrop where mostly above timberline. Several mountain species (Andreaea rupestris, Anoectangium stracheyanum, Bucklandiella microcarpa, Cynodontium strumiferum, Dicranodontium denudatum, Hygrohypnella ochracea, Isopterygiopsis muelleriana, Ochyraea duriuscula, Pseudohygrohypnum subeugyrium, Rhabdoweisia crispata) occur on rocks both in the alpine and in the forest belt. It is worthy to mention several species that are mostly associated with oceanic conditions, growing in alpine belt: Oedipodium griffithianum, Pseudotaxiphyllum elegans and Sphagnum alaskense, though in the forest belt suboceanic/east asian species occur as well.

Unlike arctic alpine liverworts, addressed by Bakalin (2015), most of which have southernmost outposts of their continental distribution in the Tardoki-Yani Mt., mosses demonstrate somewhat other phytogeographic pattern, as they usually have isolated localities southward, mostly restricted to high mountain regions. For example, Arc- toa fulvella, Aulacomnium turgidum, Bartramia ithyphylla, Brachythecium cirrosum, and Pohlia drummondii occur in Chang-Bai Mts. (Koponen et al., 1983), the closest rather well studied valuable southern outpost of arctic alpine moss flora in continental East Asia. According to "A checklist of Chinese mosses" (http://www.mobot. org/MOBOT/moss/China/chltoc.html), most of the other listed species with "arctic alpine or generally more northern distribution" occur in China as well. Among few exceptions are Dicranum angustum, Loeskypnum badium, Hygrohypnella polaris, Conostomum tetragonum, Racomitrium panschii and Stereodon holmenii. At the same time, Hygrohypnella ochracea and Racomitrium panschii occur in Primorsky Territory (Bardunov \& Cherdantseva, 1982; Ignatova, 2016). Thus, Tardoki-Yani Mt. can be considered as a southernmost outpost of continental distribution only for a few species.

At the same time, most of remaining species occur in Japan (Suzuki, 2016) and Kuril Islands (Bakalin et al., 2009, author's unpublished data). This fact partly supports Bakalin's estimation that within the insular part of the Far East changes in flora composition from north to south are more gradual than in continental part (Bakalin, 2010).

In his paper on hepatic flora of the Tardoki-Yani Mt., Bakalin (2015) considered Tardoki-Yani Mt. as the largest southern refugium of arctic-alpine liverwort flora in continental East Asia. Taking into account high concentration of species with generally more northern distribution, our results indicate that the latter approval can be extended to all bryophytes. Populations of several arcticalpine vascular plants (Cassiope ericoides, C. redowskii, Ledum decumbens, Rhododendron aureum, R. parvifolium, $R$. redowskianum, Salix saxatilis, S. phlebophylla, Carex rigidioides, C. tenuiformis, C. stans, Saussurea kitamurana, Luzula oligantha, Scorzonera radiata, Gentiana algida, cf. Vyshin, 1990). have been revealed in the Tardoki-Yani Mt. as well. According to Golubeva \& Karaulova (1983), arctic-alpine and montane species started colonizing the area from lower Pleistocene cooling and especially during cryochron, corresponding to Sartan glaciation of Siberia.

The unique mesoclimatic conditions and vegetation in the summit area of the Tardoki-Yani Mt. are suitable not only for arctic-alpine species, but also for some rare species with other patterns of distribution. The pattern of geographical distribution of Oedipodium griffithianum apparently is most remarkably different from distribution of arctic-alpine species. Schofield (1980) considered it as circum-alpine species, i.e., associated with montane area, but not with the Arctic. In Northern Hemisphere it has highly disjunctive amphioceanic distribution, mostly associated with temperate climate. It was first discovered in Russia on the Olkhovaya Mt. in southern part of Primorsky Territory (Ignatov et al., 2006). Shortly afterwards, the species was collected in the Lanzhinskie Mts. 
near the Okhotsk Town (Cherdantseva et al., 2009). Recent exploration of the moss flora of Magadan Province revealed one more locality of the species in alpine belt of the Kamenny Range near the the Okhotsk Sea coast. Consequently, the bryofloristic exploration of the TardokiYani Mt. revealed one more locality of the species (Bakalin, 2015), where it is rather abundant in the alpine belt. In most of these four localities the species bears gametangia, sporophytes and gemmae. So it can be argued that Oedipodium is able to support the local population in these localities/habitats. It is quite important remark, taking into account that the species is being considered as a relict. Due to its large spores and gemmae, it is unlikely that Oedipodium could form such geographical pattern as a result of long-dispersal events. Some primitive morphological characters as well as molecular data unambiguously suggest toward basal and well isolated taxonomic position of Oedipodium, accepted in all recent schemes of high level bryophyte taxonomy. The ecology of the species, which avoids sites with high competition and settles in rather stable conditions of alpine and subalpine belts, also indicates its relic nature. These features indicate that Oedipodium should be considered as an important phytogeographical marker, which seems to be a rather constant element of alpine flora of the Sea of Okhotsk continental coast. It undoubtfully reflects more ancient temperate connections of the studied alpine flora, compared with the arctic-alpine species that recently colonized the Tardoki-Yani Mt.

The unusual specimen representing the genus $\mathrm{Di}$ cranum is an additional intriguing record, which could be considered while discussing on the origin of the TardokiYani alpine moss flora. In well-expressed longitudinal cuticular papillae on leaf surface, it resembles Hymenoloma crispulum; however, structure of alar group in this specimen better fits to Dicranum. Previous molecular study did not help with the identification of this specimen. Later on, when new data appeared, molecular-phylogenetic reconstruction indicated its rather close relation to the temperate $D$. viride. However, recent molecular phylogenetic studies of this group (Ignatova \& Fedosov, 2008) demonstrated that specimens from East Asia represent a separate taxon, $D$. hakkodense. More detailed revision of $D$. viride s.l. complex is needed in order to delineate status of different populations and of the present specimen. The latter may represent poorly known cold-temperate East-Asian taxon.

One more temperate species indicating southern connection of alpine/subalpine flora is Brachythecium garovaglioides, a widespread species in Japan, China and Nepal.

Remarkably, all aforementioned collections have been made during short field trip by undergraduate student (Ermolenko) and specialist in hepatics (Bakalin). Such concentration of heterogeneous, phytogeographically important moss species suggests that the Tardoki-Yani Mt. is a key place for understanding of the origin of the moss flora of the Russian Far East, which deserves both further study and efforts to its preservation.

\section{ACKNOWLEDGEMENTS}

Authors are grateful to Elena Ignatova for help in identifying problematic specimens and Dolgor Tubanova for providing alignment of Dicranum, used to estimate affinity of our mysterious Dicranum specimen. Figure 1 was kindly compiled by Mr. D.A. Bakalin to whom authors are sincerely grateful. The study was partially supported by grants from the Russian Foundation the Basic Researches \#15-34-20101.

\section{LITERATURE CITED}

[AFONINA, O.M.] АФОНИНА О.М. 2004. Конспект флоры мхов Чукотки. - [Moss flora of Chukotka] СПб, БИН РАН [Sankt-Petersburg, Bot. Inst. RAS], 260 pp.

BAKALIN, V.A. 2010. Distribution of bryophytes in the Russian Far East. Part. I. Hepatics. - Vladivostok, Izd-vo DVFU, 175 pp.

BAKALIN, V.A. 2015. Tardoki-Yani Range (North Sikhote-Alin, Pacific Russia) - the largest southern refugium of arctic-alpine liverwort flora in East Asia. - Arctoa 24 (2): 314-326.

BAKALIN, V.A., V.YA. CHERDANTSEVA, M.S. IGNATOV, E.A. IGNATOVA \& T.I. NYUSHKO. 2009. Bryophyte flora of the South Kuril Islands (East Asia). - Arctoa 18: 69-114.

BAKALIN, V.A., V.YA. CHERDANTSEVA, M.S. IGNATOV, E.A. IGNATOVA \& T.I. NYUSHKO. 2009. Bryophyte flora of the South Kuril Islands (East Asia). - Arctoa 18: 69-114.

[BARDUNOV, L.V. \& V.YA. CHERDANTSEVA] БАРДУНОВ Л.В., В.Я. ЧЕРДАНЦЕВА 1982. Листостебельные мхи Южного Приморья. - [Mosses of the South of Primorskij Territory] Новосибирск, Наука [Novosibirsk, Nauka], 208 pp.

[BARDUNOV, L.V., S.K. GAMBARYAN \& V.YA. CHERDANTSEVA] БАРДУНОВ Л.В., С.К. ГАМБАРЯН, В.Я. ЧЕРДАНЦЕВА. 1990. Мохообразные. - [Bryophytes] В кн.: Флора, мико- и лихенобиота Лазовского заповедника [Flora, miko i lihenobiota Lazovskogo zapovednika]. Владивосток [Vladivostok]: 35-60.

[BARDUNOV, L.V. \& V.YA. CHERDANTSEVA] БАРДУНОВ Л.В., В.Я. ЧЕРДАНЦЕВА. 1978. Мохообразные. - [Bryophytes] $B$ кн.: Флора и растительность Уссурийского заповедника [Flora $i$ rastitel'nost' ussurijskogo zapovednika]. M., Hаука [Moscow, Nauka]: $127-148$

[CHERDANTSEVA, V.YA.] ЧЕРДАНЦЕВА В.Я. 2002. Листостебельные мхи Сихотэ-Алинского биосферного заповедника (Дальний Восток, Приморский край). - [Mosses of the Sikhote-Alinsky Biosphere Reserve (Russian Far East, Primorsky Territory)] Arctoa 11: 229-244.

CHERDANTSEVA, V.YA., M.S. IGNATOV \& V.A. BAKALIN. 2009. New moss records from Khabarovsk Territory. 1. - Arctoa 19: 279.

[FEDOSOV, V.E. \& A.V. FEDOROVA] ФЕДОСОВ В.Э., А.В. ФЕДОРОВА. 2015. Предварительные итоги молекулярно-филогенетического исследования российских представителей Seligeriaceae. [Preliminary results of molecular phylogenetic analysis of Seligeriaceae, based on species from Russia and adjacent countries]. В сб.: Mameриаль международной бриологической конференции, посвященной 100-летию со дня рождения Анастасии Лаврентьевны Абрамовой [Proceedings of the international Bryological conference devoted to the $100^{\text {th }}$ Anniversary of Anastasiya Lavrentievna Abramova]. C-Пб. [Saint-Peterburg]: 153-157.

[GAMBARYAN, S.K. \& V.YA. CHERDANTSEVA] ГАМБАРЯН C.K., В.Я. ЧЕРДАНЦЕВА. 2002. Мохообразные - [Bryophytes] В кн.: Кадастр растений и грибов заповедника "Кедровая падь": Списки видов [Kadastr rastenij i gribov zapovednika Kedrovaya Pad', spiski vidov]. Владивосток, Дальнаука [Vladivostok, Dal'nauka]: 21-30 
[GOLUBEVA, L.V. \& L.P. KARAULOVA] ГОЛУБЕВА Л.В., Л.П. КАРАУЛОВА. 1983. Растительность и климатостратиграфия плейстоцена и голоцена юга Дальнего Востока СССР - [Vegetation and climate stratigraphy of Pleistocene and Holocene in the South of the USSR Far East] M., Наука [Moscow, Nauka], 143.

IGNATOV, M.S. 1994. Bryophytes of Altai Mountains. I. Study area and history of its bryological exploration. - Arctoa 3: 13-27.

IGNATOV, M.S., O.M. AFONINA, E.A. IGNATOVA et al. 2006. Checklist of mosses of East Europe and North Asia. - Arctoa 15: 1-130.

IGNATOV, M.S., E.A. IGNATOVA \& V.YA. CHERDANTSEVA. 2006. Oedipodium griffithianum (Oedipodiopsida, Bryophyta) - new species and new class for Russian flora. - Arctoa 15: 211-214.

IGNATOV, M.S., IGNATOVA E.A. \& E.V. MALASHKINA. 2013. Ephemerum spinulosum Bruch \& Schimp. (Bryophyta), a new species for Russia. - Arctoa 22: 97-100.

IGNATOV, M.S., T. SUZUKI \& V. YA. CHERDANTSEVA. 2007. Fissidens hyalinus (Fissidentaceae, Bryophyta), a new species for Russia. - Arctoa 16: 123-126.

IGNATOVA, E.A, V.YA. CHERDANTSEVA, O.V. IVANOV, I.V. KOSTOMAROVA \& M.S. IGNATOV. 2013. A preliminary list of mosses of the Botchinsky Nature Reserve (Russian far East). - Arctoa 22: $207-216$.
IGNATOVA, E.A., V.E. FEDOSOV. 2008. Species of Dicranum (Dicranaceae, Bryophyta) with fragile leaves in Russia. - Arctoa 17: 63-83.

KOPONEN, T., C. GAO, J.S. LOU \& I. JÄRVINEN. 1983. Bryophytes from Mt. Changbai, Jilin Province, Northeast China. - Annales Botanici Fennici 20: 215-232.

SUZUKI, T. 2016. A revised new catalog of the mosses of Japan. - Hattoria, 7: 9-223.

MAKSIMOV, A.I., V.E. FEDOSOV \& E.A. IGNATOVA.2016. Sphagnum beringiense (Sphgnaceae, Bryophyta) in Russia. - Arctoa 25 (1): 102-106.

MAKSIMOV, A.I. \& E.A. IGNATOVA. 2008. Sphagnum alaskense (Sphagnaceae, Bryophyta), a new species for Russia. - Arctoa 17: 109 112.

SCHOFIELD, W.B. 1980. Phytogeography of the mosses of North America (North of Mexico). - In: Taylor, R. J. \& A. E. Leviton (eds.) The mosses of North America. San Francisco, Pacific Division/American Association for the Advancement of Science: 131-170.

[VYSHIN, I.B.] ВЫШИН И.Б. 1990. Сосудистые растения высокогорий Сихотэ-Алиня [Vascular plants of Sikhote-Alin highlands] Владивосток, Дальнаука [Vladivostok, Dal'nauka], 128 pp. 